\title{
Affinity chromatography of native and recombinant proteins from receptors for insulin and IGF-I to recombinant single chain antibodies
}

\author{
Yoko Fujita-Yamaguchi ${ }^{*}$ \\ Department of Diabetes Complications and Metabolism, Beckman Research Institute of City of Hope, Duarte, CA, USA
}

Affinity chromatography is an efficient method to isolate proteins by taking advantage of their affinities for specific molecules such as substrates, inhibitors, antigens, ligands, antibodies, and other interacting molecules, including subunits. Nowadays, we take the effectiveness and excellence of this technology for granted. This essay will mainly cover the use of affinity chromatography based on my experience.

Keywords: affinity chromatography, insulin, IGF-I, receptors, single-chain antibodies

OPEN ACCESS

Edited by:

Briony Forbes,

Flinders University of South Australia,

Australia

Reviewed by:

John D. Wade,

Florey Institute of Neuroscience and

Mental Health, Australia

Jean Albert Boutin,

Institut de Recherches Servier, France

*Correspondence: Yoko Fujita-Yamaguchi yyamaguchi@coh.org

Specialty section: This article was submitted to

Molecular and Structural Endocrinology, a section of the journal Frontiers in Endocrinology

Received: 01 September 2015 Accepted: 12 October 2015 Published: 27 October 2015

Citation:

Fujita-Yamaguchi Y (2015) Affinity

chromatography of native and recombinant proteins from receptors for insulin and IGF-I to recombinant

single chain antibodies.

Front. Endocrinol. 6:166.

doi: 10.3389/fendo.2015.00166

\section{INTRODUCTION}

Early in my career, I prepared and used five different affinity adsorbents by utilizing different types of interactions (Table 1) (1-5). Later in my career, I used commercially available affinity columns and beads, which specifically bind to tags or fusion proteins designed for purification of antibodies and recombinant proteins (Table 1) (6-11). Before the introduction of affinity chromatography, however, purification of a protein, which is not abundant in tissues, was not an easy task. Conventional procedures used before the affinity chromatography era included ammonium sulfate precipitation, ion-exchange chromatography, hydrophobic interaction chromatography, gelexclusion chromatography, isoelectric focusing, etc., which gave only around five-fold purification with about a 50\% recovery at each step. Depending upon how much and what kinds of contaminating proteins were in the starting materials, purification of a protein required a combination of at least four to five conventional methods, as above, that was labor intensive. Even if successful, that hard work often resulted in purification of a protein in an overall very low yield.

Affinity chromatography in general is concisely reviewed by Urh et al. (12). Drs. Cuatrecasas and Anfinsen were the first to introduce practical affinity chromatography $(13,14)$. Unlike conventional column chromatography, an enzyme was purified by passing it through a column containing a cross-linked polymer (or gel) to which a specific competitive inhibitor of the enzyme was covalently attached (13). All proteins without substantial affinity for the bound inhibitor passed through the column, whereas one that recognized the inhibitor bound to or was retarded in proportion to its affinity constant. Elution of the bound enzyme was readily achieved by changing conditions contributing to the binding such as a salt concentration and/or $\mathrm{pH}$, or by the addition of a competitive inhibitor in a buffer solution.

In the original publication (13), the general principles and potential applications of affinity chromatography were well demonstrated by purification of Staphylococcal nuclease, $\alpha$-chymotrypsin, and carboxypeptidase A. The solid matrix used in these studies was Sepharose (agarose, a "beaded" form of cross-linked dextran with a highly porous structure), which is still widely used for commercially available affinity columns. Activation of the Sepharose by treatment with cyanogen bromide 
TABLE 1 | Examples of different affinity chromatographies

\begin{tabular}{|c|c|c|c|c|}
\hline Reference & Affinity gels & $\begin{array}{l}\text { Immobilized specific } \\
\text { molecules }\end{array}$ & Protein purified & Fold purification \\
\hline (1) & Gum arabic cross-linked gel & $\begin{array}{l}\text { Branched polymers of } \\
\text { galactose, rhamnose, } \\
\text { arabinose, etc. }\end{array}$ & SHA (Streptomyces lectin) & 13,300 \\
\hline (2) & $\alpha$-Lactalbumin-Sepharose & $\begin{array}{l}\alpha-\llcorner A \text { (lactose synthetase B } \\
\text { protein) }\end{array}$ & $\begin{array}{l}\text { Galactosyltransferase (lactose } \\
\text { synthetase A protein) }\end{array}$ & 286,000 \\
\hline (3) & Insulin-Sepharose & Insulin & Insulin receptor & 330 From WGA-Sepharose eluates \\
\hline (4) & $\alpha \mathrm{IR3}-S e p h a r o s e$ & Anti-IGF-I receptor mAb & IGF-I receptor & 460 From WGA-Sepharose eluates \\
\hline (5) & CIT-Sepharose & PDE3 inhibitor & $\begin{array}{l}\text { cGMP-inhibited low Km cAMP } \\
\text { PDE (cGl-PDE) }\end{array}$ & 5,700 \\
\hline$(6-8)$ & Protein A-Sepharose & Protein A & scFv-Fcs & ND \\
\hline (7) & Glutathione Sepharose 4B beads & Glutathione & GST-scFvs & ND \\
\hline$(8-11)$ & $\mathrm{Ni}^{2+}$-Sepharose & $\mathrm{Ni}^{2+}$ & scFvs with His-tag & ND \\
\hline
\end{tabular}

results in a derivative that can be readily coupled to unprotonated amino groups of specific molecules having high affinities for the proteins of interest. The resultant specific molecule-coupled Sepharose is a highly stable structure which has nearly ideal properties for selective column chromatography (14). A similar approach to this was applied to purification of cGMP-inhibited low Km cAMP PDE (cGI-PDE) (Table 1) (5).

\section{AFFINITY CHROMATOGRAPHY EXPERIMENTS PRIOR TO PURIFICATION OF THE INSULIN RECEPTOR}

As a graduate student at the University of Tokyo in the mid 1970 s, after struggling with conventional purification procedures, I was introduced to affinity chromatography. I prepared affinity adsorbents by cross-linking commercially available gum arabic, a product of acacia trees. Its structure is still unsolved, but believed to be a branched polymer of galactose, rhamnose, arabinose, and glucuronic acid with an average molecular mass of 250,000. Since my previous study revealed that the hemagglutination activity of Streptomyces hemagglutinin (SHA), a lectin secreted by Streptomyces sp. 27S5, was inhibited by L-rhamnose, D-galactose, Larabinose, and plant polysaccharides, including gum arabic (15), gum arabic was cross-linked by epichlorohydrin according to the method for preparation of Sephadex. The solidified gum arabic was broken into small pieces, which were washed thoroughly. The gum arabic polymer gels were used to purify SHA from $15 \mathrm{l}$ of culture supernatants of Streptomyces sp. 27S5 using a one-step batch-to-column chromatography achieving 13,300-fold purification with a yield of $60 \mathrm{mg}$ and $64 \%$ recovery of the total activity (1). This was quite an accomplishment when compared to the conventional five step-purifications performed prior to the affinity purification, which resulted in only 190 -fold purification with $0.006 \%$ recovery of the total activity from the starting material (15). We found in 2014 that the purified SHA kept frozen since 1974 was intact with respect to molecular mass and hemagglutination activity. New structural and functional studies are now in progress (16).

Second, quite a unique affinity chromatography was carried out to purify UDP-Gal:GlcNAc $\beta 4$-galactosyltransferase from human sera (2). It had been known that lactose synthetase is composed of two protein components; UDP-Gal:GlcNAc $\beta 4$ galactosyltransferase (A protein) and $\alpha$-lactoalbumin ( $\alpha$-LA) (17). By taking advantage of subunit interactions for the affinity column design, $\alpha$-LA was mixed with cyanogen bromideactivated Sepharose which yielded $6.1 \mathrm{mg} \alpha$-LA/ml of gel (2). $\alpha$ LA binding to A protein changes the acceptor specificity of $\mathrm{A}$ protein, which recognizes glucose as an acceptor, thus allowing the synthesis of lactose. Therefore, galactosyltransferase (A protein) was purified by applying human sera to $\alpha$-LA-Sepharose in the presence of $\mathrm{Mg}^{2+}$ and GlcNAc, which allows A protein binding to $\alpha$-LA in the column. Galactosyltransferase (A protein) was eluted from the column by the buffer lacking GlcNAc. From $155 \mathrm{~g}$ of total serum proteins, $220 \mu \mathrm{g}$ of galactosyltransferase was purified by two $\alpha$-LA-Sepharose chromatographies. The first column $(2.5 \mathrm{~cm} \times 12 \mathrm{~cm})$ was used to bind the enzyme from 3.41 of sera, whereas the reduced-size second column $(0.5 \mathrm{~cm} \times 10 \mathrm{~cm})$ was used to concentrate and thoroughly remove non-specific proteins. The overall 286,000 -fold purification was achieved with $40 \%$ recovery of the total activity (2). This work was done during my post-doctoral period as a result of a spin-off of the assignment given by my mentor.

\section{PURIFICATION OF BIOLOGICALLY ACTIVE INSULIN RECEPTOR: THE SAME INSULIN-SEPHAROSE COLUMN HAD BEEN USED OVER 250 TIMES TO PURIFY IR WITH FULL BINDING AND TYROSINE KINASE ACTIVITIES}

When I started to become an independent researcher at City of Hope, Dr. Keiichi Itakura and I wrote an NIH grant in which two aims were proposed. Aim 1 was to purify human insulin receptor (IR) and Aim 2 was to clone IR cDNA. By that time, I was a well-qualified protein chemist able to carry out Aim 1 whereas Dr. Itakura was very successful in manually synthesizing oligonucleotides long before automated DNA synthesizers became commercially available. Aim 2 was to use mixed oligonucleotides designed based on amino acid sequences of IR peptides as probes to clone cDNA encoding IR mRNA. To make a long story short, we were successful in purifying and obtaining amino acid sequences 
of IR peptides, but not in screening of cDNA encoding IR by the proposed mixed oligonucleotide probes. As it turned out, our strategy of using mixed oligonucleotides consisting of all possible codon combinations of amino acid sequences which inevitably contained 8 or 16 mixtures resulted in high levels of non-specific hybridizations to messages much more abundant than IR. By contrast, Dr. Axel Ulrich's team at Genentech was successful in screening IR cDNA by using a long single DNA probe, which was designed based on codon usage. They also successfully used such a long probe consisting of $78 \mathrm{nt}$ for the cloning of IGF-I receptor, which we purified and provided them for determination of N-terminal and peptide sequences (18).

We purified human IR from placenta by insulin affinity chromatography with new elution conditions modified from published protocols (3). Porcine insulin was conjugated to Sepharose according to the methods previously published by Cuatrecasas $(14,19)$. Insulin affinity chromatography had been carried out before us to purify IR. The resulting preparations were, however, not proven to be adequately pure but rather considered as a partial or incomplete purification because they did not reach a theoretical specific activity of $20 \mathrm{pg}$ of insulin bound per milligram of protein when assuming IR with $\mathrm{Mr}=300,000$ binds one molecule of insulin. For example, Jacobs et al. reported the purification of IR from rat liver by insulin affinity chromatography in 1977 (20), but specific activity was $2.4 \mathrm{pg}$ of insulin bound per milligram of protein. Siegel et al. purified human placental IR with a specific activity of $5.1 \mathrm{pg}$ of insulin bound per milligram of protein using DEAEcellulose chromatography and insulin-Sepharose chromatography (21). Such low specific activities could be due to contaminants in the purified receptor preparations (not yet completely purified) or to inactivation of the receptor (pure but having lost its activity). The major drawback of the insulin-Sepharose chromatography procedures introduced by Jacobs et al. (20) was that insulinbinding activity could be inactivated during elution from the column with $50 \mathrm{mM}$ acetate buffer, $\mathrm{pH}$ 6, containing 4.5M urea.

We used two affinity columns to purify IR from human placenta. The first step was to purify glycoproteins from Triton X100 solubilized placenta membranes by WGA-Sepharose chromatography. WGA-Shepharose bound glycoproteins contained IR as well as IGF-I receptor. As the second step of purification, the glycoprotein fractions were applied to the insulin-Sepharose column, which had been equilibrated with $50 \mathrm{mM}$ Tris-HC1 buffer, $\mathrm{pH} 7.4$, containing $1 \mathrm{M} \mathrm{NaCl}, 0.1 \%$ Triton X-100, and protease inhibitors. The column was washed extensively with this buffer. The column was eluted with $50 \mathrm{mM}$ acetate buffer, $\mathrm{pH} 5$, containing $1 \mathrm{M} \mathrm{NaCl}, 0.1 \%$ Triton $\mathrm{X}-100$, and protease inhibitors.

The purified receptor had a high specific activity of $28.5 \mathrm{pg}$ of insulin bound per milligram of protein, confirming apparent homogeneity of the preparation (3). Since the reviewer asked us to compare the two elution conditions, a half amount of WGASepharose eluates was applied to the insulin-Sepharose column from which IR was eluted by $50 \mathrm{mM}$ acetate buffer, $\mathrm{pH} 6$, containing $4.5 \mathrm{M}$ urea and the other half was applied to the same column from which IR was eluted by our high salt $(1 \mathrm{M} \mathrm{NaCl})$ and low $\mathrm{pH}(\mathrm{pH}$ 5) elution conditions. The comparison of the elution profiles of insulin binding activity [Figure 1 and Table 2 in Ref. (3)] clearly demonstrated that IR eluted by the previously used urea-containing buffer gave a much smaller activity peak that was about one-fifth of the insulin binding activity as compared to the receptor eluted with the new conditions. This experiment demonstrated that IR was inactivated by $4.5 \mathrm{M}$ urea included in the elution buffer.

Our purified IR exhibited a theoretically reasonable number of binding sites and an intact $\beta$ subunit which exhibited tyrosine kinase activity $(3,22)$. Previous studies demonstrated by crosslinking ${ }^{125}$ I-insulin to membrane bound IR and subsequent SDSPAGE that IR contained $\alpha, \beta$, and $\beta 1$ subunits (23). It was later found that the $\beta 1$ subunit lacks the cytoplasmic kinase domain due to proteolytic degradation during preparations of IR. Furthermore, most of the purified IR reported earlier significantly lacked an intact $\beta$ subunit although it contained $\alpha$ and $\beta 1$ subunits, whereas our purified IR contained a high level of the intact $\beta$ subunit in addition to the stable $\alpha$ subunit. Peptide mapping of purified $\beta$ and $\beta 1$ subunits directly demonstrated that the $\beta 1$ subunit was a part of the $\beta$ subunit (24).

Around the time we purified IR, newly found IR kinase activity was being characterized using cell homogenates and partially purified IR mainly by Dr. Masato Kasuga in Dr. Ronald Kahn's laboratory $(25,26)$. Our collaboration started right away to characterize IR kinase using the purified IR. I had some doubt about the presence of an intrinsic kinase in IR since it is possible that a trace amount of protein kinases could be a contaminant in the purified IR. In fact, in the case of proteases, we found that endogenous proteases were contaminated and gradually digested the IR $\beta$ subunit during storage or freezing and thawing of the purified receptors (27). During such a degradation process, the $\beta$ subunit lost kinase activity, revealing that the $\beta 1$ subunit no longer carried the kinase domain. This observation was consistent with the fact that the $\beta$ subunit could be easily degraded to the core $\beta 1$ subunit during IR preparations.

The insulin-Sepharose column $(2 \mathrm{~cm} \times 8 \mathrm{~cm})$ was reused repeatedly. The column was kept in the elution buffer and equilibrated just before using. We used the same column to purify IR 283 times. This is really remarkable since affinity columns usually lose ligands after using 10-20 times. The IR carried both insulin binding and kinase activities even until the last preparation in 1991. Why we purified IR that many times is a very good question. The preparations were used not only for amino acid sequence determination for the original cloning project but also for characterizing specific binding and kinase activity as well as interaction with other signaling molecules. Together with the purified IGF-I receptor, the purified IR had provided excellent material to definitively determine intrinsic natures of these receptors, which could not have been achieved by using impure materials containing both receptors.

\section{IGF-I RECEPTOR WAS PURIFIED FROM PASSED-THROUGH FRACTIONS OF THE INSULIN-SEPHAROSE COLUMN BY AN ANTI-IGF-I RECEPTOR mAb-SEPHAROSE COLUMN 80 TIMES}

Nowadays, we take for granted that recombinant technology provides us with most proteins of our interests. During 1983-1985, however, IGF-I was not commercially available unlike porcine 
insulin. Porcine insulin has the same affinity for human IR as human insulin so that there was no problem with its supply for preparing the insulin-Sepharose column and assaying insulin binding activity. In the case of IGFs, the situation was quite different from insulin. Only three laboratories in the world were purifying IGFs from human sera. Thus, purification of the human IGF-I receptor was carried out in collaboration with Drs. Jacobs and Cuatrecusas who provided us with not only IGF-I but also anti-IGF-I receptor $\mathrm{mAb}$ called $\alpha \operatorname{IR}-3$ (28).

After the first step of purification by WGA-Sepharose, glycoprotein fractions were applied to the insulin-Sepharose column. Unbound passed-through fractions from the insulin-Sepharose column, which should have contained IGF-I receptor were kept frozen. The frozen WGA-Sepharose eluate prepared from a total of 21 placentas was applied to a $2-\mathrm{cm} \times 6.4-\mathrm{cm} \alpha$ IR-3 Sepharose column $(0.5 \mathrm{mg}$ of antibody/ml of gel) equilibrated with $50 \mathrm{mM}$ Tris-HC1 buffer, $\mathrm{pH} 7.4$, containing $1 \mathrm{M} \mathrm{NaCl}, 0.1 \%$ Triton X-100, and protease inhibitors. The column was washed extensively with this buffer. The receptor was eluted with $50 \mathrm{mM}$ acetate buffer, $\mathrm{pH} 5$, containing $1 \mathrm{M} \mathrm{NaCl}, 0.1 \%$ Triton $\mathrm{X}-100$, and protease inhibitors, and then with $1 \mathrm{M}$ glycine buffer, $\mathrm{pH} 2.2$, containing $1 \mathrm{M} \mathrm{NaCl}, 0.1 \%$ Triton X-100, and protease inhibitors. Fractions $(2 \mathrm{ml})$ were collected in tubes containing $3 \mathrm{ml}$ of $0.5 \mathrm{M}$ Tris to neutralize the eluates. Fractions containing IGF-I binding activity appeared in the $\mathrm{pH} 5$ elution (Fraction I) and the $\mathrm{pH} 2.2$ elution (Fraction II). Fraction I contained an active IGF-I receptor but a low level of the receptor, whereas Fraction II contained substantial amounts of the receptor with reduced IGF-I binding activity (4). Fraction I was used for binding and kinase assays while Fraction II was used for amino acid sequence determination which led to cloning of the cDNA encoding human IGF-I receptor in collaboration with Drs. Ullrich and Ramachandran at Genentech as mentioned above (18). We used the same $\alpha$ IR-3 Sepharose column to purify IGF-I receptor 80 times. This is also a significant achievement.

\section{AFFINITY CHROMATOGRAPHY FOR RECOMBINANT PROTEINS}

Addition of an affinity tag is an effective method for differentiating recombinant proteins expressed in bacterial and eukaryotic expression systems from the endogenous cellular proteins. The tags can be utilized for purification as well as for detecting specifically tagged recombinant proteins. The historical basis for the development of affinity tags and how to choose an appropriate affinity tag for a particular purpose are summarized in reviews $(29,30)$.

A variety of affinity columns combined with expression vectors designed to express proteins of interest with affinity tags are now commercially available. Protocols are provided by manufacturers, and thus it looks easy to express and purify recombinant proteins from cDNAs encoding proteins of interest. It requires, however, experience in purification and modification of the protocols to achieve the best outcome. Here are a few examples of those which we have worked out.

\section{PROTEIN A-SEPHAROSE CHROMATOGRAPHY}

To purify recombinant single chain antibodies ( $\mathrm{scFvs}$ ), we used expression vectors (not commercially available) to produce human IgG1Fc-conjugated $s c F v$ in mammalian cells (6-8). Culture supernatants collected from $\alpha$ IGF-IR-scFv-Fc-expressing NS0 cells were adjusted to $\mathrm{pH} 8.0$ by adding $1 / 20$ volume $1.0 \mathrm{M}$ Tris ( $\mathrm{pH} 8.0$ ), and passed through a protein-A Sepharose column $(1 \mathrm{ml})$. The column was washed with 10 column volumes of $100 \mathrm{mM}$ Tris-HCl buffer, $\mathrm{pH}$ 8.0. $\alpha$ IGF-IR scFv-Fc was eluted from the column with $100 \mathrm{mM}$ glycine buffer, $\mathrm{pH} 3.0$, and collected in $1.5-\mathrm{ml}$ conical tubes containing $1 / 10$ volume of $1 \mathrm{M}$ Tris, pH 8.0 (6).

Anti-carbohydrate (Man3) 5A3 and (Le ${ }^{\mathrm{X}}$ ) 1F12 scFv-Fcs were similarly purified with slight modifications to accommodate the need for each preparation $(7,8)$. If cells can be adapted to growth in SFM, then contamination of bovine IgGs from FCS can be avoided (7). If cells were grown in media containing FCS, scFcFcs and bovine IgGs would be eluted together using pH 3.0 buffer. Thus, contaminating bovine IgG had to be eluted from the column with $\mathrm{pH}$ 5.0-buffer before elution of scFv-Fc proteins by $\mathrm{pH} 3.0$ buffer (8).

\section{EXPRESSION AND PURIFICATION OF SCFV PROTEINS IN E. coli}

Production of soluble scFvs in Escherichia coli requires proper disulfide bond formation, which is not easy to achieve. To circumvent this problem, fusion proteins, which can be expressed as soluble forms in $E$. coli are often used. The glutathione $S$-transferasetag is one good example. It was used to purify anti-carbohydrate scFvs from E. coli crude homogenates by glutathione-affinity column chromatography (7).

The most useful tag for purification of recombinant proteins was and is the poly-histidine tag (His-tag) (29, 31). His-tag consisting of six His interacts with a transition metal ion, such as $\mathrm{Ni}^{2+}$ and $\mathrm{Co}^{2+}$, which is the basis for immobilized metalaffinity chromatography (IMAC). As described above, in bacterial cells, recombinant proteins usually fail to fold properly and accumulate as insoluble particles called inclusion bodies. Inclusion bodies are considered to be formed by non-specific hydrophobic interactions between irregularly deposited polypeptides. Those protein aggregates could provide a good reservoir of sufficient amounts of functional scFv proteins if highly efficient refolding of denatured $\mathrm{scFv}$ proteins can be achieved. In our laboratory, $\mathrm{scFv}$ proteins were purified as denatured proteins by IMAC from inclusion bodies in the presence of $3.5 \mathrm{M} \mathrm{Gdn}-\mathrm{HCl}$, and the $\mathrm{scFv}$ proteins were successfully folded using the stepwise dialysis method (8-11). 


\section{CONCLUSION}

Affinity chromatography remains a crucial core technology for the purification of native and recombinant proteins, and affords consistently a high level of resolution and recovery.

\section{REFERENCES}

1. Fujita Y, Oishi K, Suzuki K, Imahori K. Purification and properties of an anti-B hemagglutinin produced by Streptomyces sp. Biochemistry (1975) 14:4465-70. doi:10.1021/bi00691a019

2. Fujita-Yamaguchi Y, Yoshida A. Purification and characterization of human serum galactosyltransferase (lactose synthetase A protein). J Biol Chem (1981) 256:2701-6.

3. Fujita-Yamaguchi Y, Choi S, Sakamoto Y, Itakura K. Purification of insulin receptor with full binding activity. J Biol Chem (1983) 258:5045-9.

4. LeBon TR, Jacobs S, Cuatrecasas P, Kathuria S, Fujita-Yamaguchi Y. Purification of insulin-like growth factor I receptor from human placental membranes. J Biol Chem (1986) 261:7685-9.

5. LeBon TR, Kasuya J, Paxton RJ, Belfrage P, Hockman S, Manganiello VC, et al. Purification and characterization of guanosine 3',5'-monophosphateinhibited low $\mathrm{K}(\mathrm{m})$ adenosine 3'5'-monophosphate phosphodiesterase from human placental cytosolic fractions. Endocrinology (1992) 130:3265-74. doi:10. 1210/endo.130.6.1317779

6. Li SL, Liang SJ, Guo N, Wu AM, Fujita-Yamaguchi Y. Single-chain antibodies against human insulin-like growth factor I receptor: expression, purification, and effect on tumor growth. Cancer Immunol Immunother (2000) 49:243-52. doi: $10.1007 /$ s002620000115

7. Zhang W, Matsumoto-Takasaki A, Kusada Y, Sakaue H, Sakai K, Nakata M, et al. Isolation and characterization of phage-displayed single chain antibodies recognizing nonreducing terminal mannose residues. 2. Expression, purification, and characterization of recombinant single chain antibodies. Biochemistry (2007) 46:263-70. doi:10.1021/bi0618767

8. Yuasa N, Ogawa H, Koizumi T, Tsukamoto K, Matsumoto-Takasaki A, Asanuma $\mathrm{H}$, et al. Construction and expression of anti-Tn-antigen-specific single-chain antibody genes from hybridoma producing MLS128 monoclonal antibody. J Biochem (2012) 151:371-81. doi:10.1093/jb/mvs007

9. Sakai K, Yuasa N, Tsukamoto K, Takasaki-Matsumoto A, Yajima Y, Sato R, et al. Isolation and characterization of antibodies against three consecutive Tnantigen clusters from a phage library displaying human single-chain variable fragments. J Biochem (2010) 147:809-17. doi:10.1093/jb/mvq014

10. Matsumoto-Takasaki A, Yuasa N, Katagiri D, Koyama T, Sakai K, Zamri N, et al. Characterization of three different single chain antibodies recognizing non-reducing terminal mannose residues expressed in Escherichia coli by an inducible T7 expression system. J Biochem (2011) 150:439-50. doi:10.1093/jb/ mvr078

11. Yuasa N, Koyama T, Subedi GP, Yamaguchi Y, Matsushita M, Fujita-Yamaguchi Y. Expression and structural characterization of anti-T-antigen single-chain antibodies (scFvs) and analysis of their binding to T-antigen by surface plasmon resonance and NMR spectroscopy. J Biochem (2013) 154:521-9. doi:10.1093/jb/ mvt089

12. Urh M, Simpson D, Zhao K. Affinity chromatography: general methods. Methods Enzymol (2009) 463:417-38. doi:10.1016/S0076-6879(09)63026-3

13. Cuatrecasas P, Wilchek M, Anfinsen CB. Selective enzyme purification by affinity chromatography. Proc Natl Acad Sci U S A (1968) 61:636-43. doi:10. 1073/pnas.61.2.636

14. Cuatrecasas P. Protein purification by affinity chromatography. Derivatizations of agarose and polyacrylamide beads. J Biol Chem (1970) 245:3059-65.

15. Fujita Y, Oishi K, Aida K. Sugar specificity of anti-B hemagglutinin produced by Streptomyces sp. Biochem Biophys Res Commun (1973) 53:495-501. doi:10. 1016/0006-291X(73)90689-X

16. Bagramyan K, Hong TB, Murad JP, Fujita-Yamaguchi Y, Kalkum, M. Mass spectrometric resurrection of SHA, a L-rhamnose and $\beta$-D-galactose binding

\section{ACKNOWLEDGMENTS}

The author thanks Drs. T. R. LeBon, S. L. Li, W. Zhang, N. Yuasa, and A. Matsumoto-Takasaki for their contribution to purify receptors and antibodies.

lectin from the lost strain Streptomyces 27S5. In: 63rd American Society for Mass Spectrometry (ASMS) Conference, ThP307; 201531 May-4 June. Saint Louis, MO (2015)

17. Brew K, Vanaman TC, Hill RL. The role of alpha-lactalbumin and the A protein in lactose synthetase: a unique mechanism for the control of a biological reaction. Proc Natl Acad Sci U S A (1968) 59:491-7. doi:10.1073/pnas.59.2.491

18. Ullrich A, Gray A, Tam AW, Yang-Feng T, Tsubokawa M, Collins C, et al. Insulin like growth factor I receptor primary structure: comparison with insulin receptor suggests structural determinants define functional specificity. $E M B O$ $J$ (1986) 5:2503-12.

19. Cuatrecasas P. Affinity chromatography and purification of the insulin receptor of liver cell membranes. Proc Natl Acad Sci U S A (1972) 69:1277-81. doi:10. 1073/pnas.69.5.1277

20. Jacobs S, Shechter Y, Bissell K, Cuatrecasas P. Purification and properties of insulin receptors from rat liver membranes. Biochem Biophys Res Commun (1977) 77:981-8. doi:10.1016/S0006-291X(77)80074-0

21. Siegel TW, Ganguly S, Jacobs S, Rosen OM, Rubin CS. Purification and properties of the human placental insulin receptor. J Biol Chem (1981) 256:9266-73.

22. Kasuga M, Fujita-Yamaguchi Y, Blithe DL, Kahn CR. Tyrosine-specific protein kinase activity is associated with the purified insulin receptor. Proc Natl Acad Sci U S A (1983) 80:2137-41. doi:10.1073/pnas.80.8.2137

23. Massague J, Pilch PF, Czech MP. A unique proteolytic cleavage site on the beta subunit of the insulin receptor. J Biol Chem (1981) 256:3182-90.

24. Fujita-Yamaguchi Y. Characterization of purified insulin receptor subunits. $J$ Biol Chem (1984) 259:1206-11.

25. Kasuga M, Karlsson FA, Kahn CR. Insulin stimulates the phosphorylation of the 95,000-dalton subunit of its own receptor. Science (1982) 215:185-7. doi:10.1126/science.7031900

26. Kasuga M, Zick Y, Blith DL, Karlsson FA, Häring HU, Kahn CR. Insulin stimulation of phosphorylation of the beta subunit of the insulin receptor Formation of both phosphoserine and phosphotyrosine. J Biol Chem (1982) 257:9891-4

27. Kathuria S, Hartman S, Grunfeld C, Ramachandran J, Fujita-Yamaguchi Y. Differential sensitivity of two functions of the insulin receptor to the associated proteolysis: kinase action and hormone binding. Proc Natl Acad Sci U S A (1986) 83:8570-4. doi:10.1073/pnas.83.22.8570

28. Kull FC Jr, Jacobs S, Su YF, Svoboda ME, Van Wyk JJ, Cuatrecasas P. Monoclonal antibodies to receptors for insulin and somatomedin-C. J Biol Chem (1983) 258:6561-6.

29. Terpe K. Overview of tag protein fusions: from molecular and biochemical fundamentals to commercial systems. Appl Microbiol Biotechnol (2003) 60:523-33. doi:10.1007/s00253-002-1158-6

30. Kimple ME, Brill AL, Pasker RL. Overview of affinity tags for protein purification. Curr Protoc Protein Sci (2013) 73:Unit9.9. doi:10.1002/0471140864. ps0909s73

31. Arnold FH. Metal-affinity separations: a new dimension in protein processing Biotechnology (1991) 9:151-6. doi:10.1038/nbt0291-151

Conflict of Interest Statement: The author declares that the research was conducted in the absence of any commercial or financial relationships that could be construed as a potential conflict of interest.

Copyright (C) 2015 Fujita-Yamaguchi. This is an open-access article distributed under the terms of the Creative Commons Attribution License (CC BY). The use, distribution or reproduction in other forums is permitted, provided the original author(s) or licensor are credited and that the original publication in this journal is cited, in accordance with accepted academic practice. No use, distribution or reproduction is permitted which does not comply with these terms. 